


\section{NOTICE}

This report is published in the interest of providing information which may prove of value to the reader in his study of effects data derived principally from nuclear weapons tests and from experiments designed to duplicate various characteristics of nuclear weapons.

This document is based on information available at the time of preparation which may have subsequently been expanded and re-evaluated. Also, in preparing this report for publication, some classified material may have been removed. Users are cautioned to avoid interretations and conclusions based on unknown or incomplete data.

PRINTED IN USA

Price $\$ 0.50$ Ayallable from the Office of Technical Services, Department of Commerce, Washington 25, D. C. 


\section{DISCLAIMER}

This report was prepared as an account of work sponsored by an agency of the United States Government. Neither the United States Government nor any agency Thereof, nor any of their employees, makes any warranty, express or implied, or assumes any legal liability or responsibility for the accuracy, completeness, or usefulness of any information, apparatus, product, or process disclosed, or represents that its use would not infringe privately owned rights. Reference herein to any specific commercial product, process, or service by trade name, trademark, manufacturer, or otherwise does not necessarily constitute or imply its endorsement, recommendation, or favoring by the United States Government or any agency thereof. The views and opinions of authors expressed herein do not necessarily state or reflect those of the United States Government or any agency thereof. 


\section{DISCLAIMER}

Portions of this document may be illegible in electronic image products. Images are produced from the best available original document. 


\title{
METHODS AND TECHNIQUES OF FALLOUT STUDIES USING A PARTICULATE SIMULANT
}

\author{
By \\ William Lee \\ and
}

Henry M. Borella

Approved by: R. L. CORSBIE

Director

Civil Effects Test Operations

U. S. Atomic Energy Commission

Edgerton, Germeshausen \& Grier, Inc.

Santa Barbara, California

August 1960 


\begin{abstract}
The fallout hazard and protection factors in current use for large groups of buildings, i.e., urban residential areas, business districts, industrial complexes, government centers, Atomic Energy Commission facilities, and academic and medical institutions, are largely unsubstantiated by experimental evidence. These data are important for personnel protection on a national basis in the event of war and on a local basis in the event of certain types of nuclear accidents. This report discusses the need for such information and suggests methods for obtaining it.

The methods suggested should provide a cross check of the data obtained on isolated structures under actual fallout conditions with the data from studies that made use of methods such as distributed point sources and a moving single-point source (as used in the Mobile Radiological Measurement Unit, Civil Effects Test Operations) to simulate actual fallout fields and with data from other studies in which predicted values of fallout protection were calculated from strictly theoretical considerations.
\end{abstract}




\section{ACKNOWLEDGMENTS}

The authors wish to express their appreciation to $R$. L. Corsbie, Director, Civil Effects Test Operations, Division of Biology and Medicine, and members of his advisory staff for their many helpful suggestions and criticisms throughout the preparation of this report.

The authors also wish to acknowledge the valuable assistance rendered by the following persons: Carl F. Miller, James D. Sartor, Philip D. LaRiviere, Hong Lee, and other members of the Naval Radiological Defense Laboratory projects at Camp Parks, Calif., and John Jacovitch, Larry Franks, Donald Horne, and other members of Edgerton, Germeshausen \& Grier, Inc., who assisted in the preparation of the final manuscript. 


\section{CONTENTS}

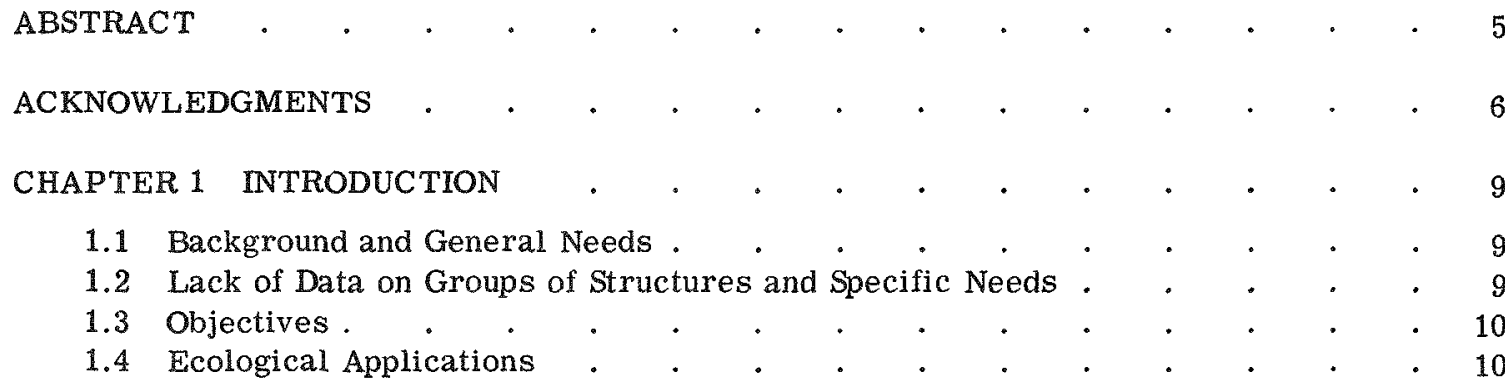

CHAPTER 2 THE FALLOUT SIMULANT PROBLEM.$\quad$. . . . . . . 12

2.1 Rationale . . . . . . . . . . . . . . . . 12

2.2 Fallout Distribution . . . . . . . . . . . . . . 12

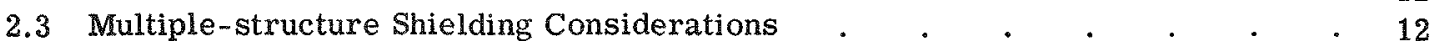

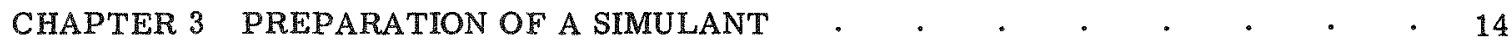

3.1 Properties and Test Conditions . . . . . . . . . . . . 14

3.2 Scaling . . . . . . . . . . . . . . 14

3.3 Materials and General Method of Preparation . . . . . . . . . . $\quad . \quad 15$

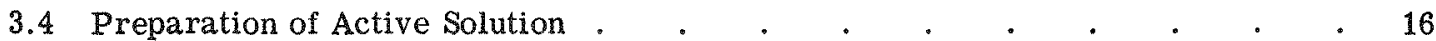

3.5 Quantity of $\mathrm{Ba}^{140}-\mathrm{La}^{140}$ Involved. . . . . . . . . . . . 16

3.6 Transport of Active Simulant . . . . . . . . . . . . . . 16

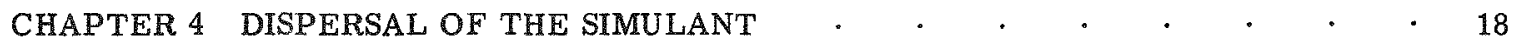

4.1 General Considerations . . . . . . . . . . . . . 18

4.2 Elevated Air- or Water-pressure Spray-nozzle System • . . . . 18

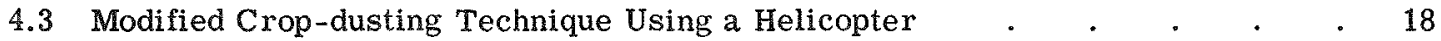

4.4 Air Showering of a Zone-melted Fuel Element $\quad . \quad$. $\quad . \quad$. $\quad . \quad$. $\quad . \quad 19$

4.5 Explosive-charge or Rapid High-pressure Gas-release System Suspended
Beneath a Balloon or Helicopter . . . . . . . 19

CHAPTER 5 DOSIMETRY . . . . . . . . . . . . . . . . 20

5.1 Dose Rates and Attenuation Factors . . . . . . . . . . . . 20

5.2 Dosimetry. . . . . . . . . . . . . . . . $\quad . \quad .20$

CHAPTER 6 CONCLUSIONS AND RECOMMENDATIONS $\quad$. . . . . . . . 22

6.1 Conclusions . . . . . . . . . . . . . . 22

6.2 Recommendations . . . . . . . . . . . . . . . . 22 
TABLES

CHAPTER 3 PREPARATION OF A SIMULAN'T

3.1 Fallout Deposition Characteristics for a 1-Mt Surface Burst . • . $\quad 15$

CHAPTER 5 INSTRUMENTATION AND RECOVERY

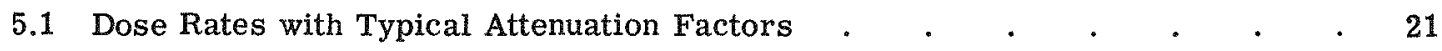




\section{Chapter 1}

\section{INTRODUCTION}

\subsection{BACKGROUND AND GENERAL NEEDS}

In the event of a massive nuclear attack by an enemy force, the ability of our highly complex and technologically dependent society to make a rapid and effective recovery will depend upon the survival of a large body of professionally trained people in various strategic centers of the nation, i.e., in government, the military, civil defense, communications, transportation, and hospitals. It has been well established ${ }^{1}$ that an adequate family-shelter system is an integral part of any total defense system against nuclear attack, since it could reduce total civilian casualties by a substantial amount. It is apparent that an adequate family-shelter system is technically feasible and that the cost of constructing or modifying isolated suburban structures to furnish fallout protection would be relatively low. ${ }^{2}$

Above-ground protective structures in built-up urban and suburban areas present more complex problems. Population density in these areas is the greatest; and, if the importance of shelters is regarded as proportional to population density, then the need for shelters is very great in and around these areas. A large proportion of skilled technical and professional people live and work in the built-up metropolitan areas, the potential target areas. During normal working hours, these people are concentrated within large industrial complexes, government establishments, and closely grouped multistoried structures typical of the large urban and metropolitan areas. In case of a daylight attack, they would be forced to take shelter in existing buildings and structures within these areas.

If a target escapes total destruction from primary effects such as heat, blast, and radiation, the remaining hazard, residual radiation, becomes the critical factor in survival. The refore reliable information concerning the residual radiation from fallout is necessary to minimize casualties and to permit rapid restoration of strategic functions. Knowledge of the expected fallout distribution patterns, as well as the relative attenuation factors to be encountered within such building complexes, is vital to the selection of adequate shelter areas and to the planning and execution of the necessary decontamination and cleanup operations.

\subsection{LACK OF DATA ON GROUPS OF STRUCTURES AND SPECIFIC NEEDS}

Previous CETO-sponsored field experiments under actual fallout conditions have provided measurements on the fallout hazard and protection factors of specially constructed shelters, ${ }^{3}$ selected materials and types of construction, ${ }^{4}$ and simple frame buildings exposed to infiniteplane doses. ${ }^{5}$ These data have proved to be very valuable in the formulation of recommendations for family-shelter programs. This information, however, cannot be directly extrapolated to the situation of the built-up areas containing complex building structures such as those considered in this report. Attempts to calculate the fallout protection factors that would exist in these areas have required the assumption of rather broad and arbitrary conditions, the validity of which is difficult to verify without additional experimental data. ${ }^{6}$ 
Fallout protection factors are conspicuously lacking for grouped buildings of various sizes and shapes constructed of different materials and situated in a variety of configurations and locations relative to each other. Similarly data are lacking for fallout distribution in such situations. In previous tests involving actual fallout, the fallout distribution has been essentially a two-dimensional infinite-plane dose pattern; whereas, for the situation under consideration, the spatial distribution of the fallout pattern would undoubtedly be three-dimensional in nature.

Although techniques are available for obtaining shielding characteristics for isolated structures (e.g., the CETO Mobile Radiological Measurement Unit moving-point-source system), no techniques are available for adequately evaluating the heterogeneous association of buildings characteristic of downtown urban and suburban residential areas, industrial complexes, school campuses, and hospitals.

Weapons effects other than fallout would further complicate the design and structure modifications needed for adequate protection. This discussion, however, is limited principally to protection against the hazards of residual radiation from fallout.

\subsection{OBJECTIVES}

The study proposed here would explore techniques by which vital experimental data needed to supplement our present knowledge of fallout hazards and protection factors can be supplied. Good data on the mutual shielding characteristics of and the fallout radiation patterns around grouped buildings are important if wise use is to be made of the information obtained from previous studies dealing with combined weapons effects ${ }^{7}$ and fallout pattern characteristics. 8.9 It seems obvious that a realistic three-dimensional fallout simulant appropriately distributed over suitable target structures would furnish a rational approach to the problem. Such a simulant is the principal subject of this report.

Data obtained from a simulant study would provide a cross check of data obtained from weapons fallout at the Nevada Test Site,${ }^{10}$ from fixed multiple sources, ${ }^{11}$ from the use of a moving point source, ${ }^{12}$ and from theoretical calculations. Such data could also be used in the exploration of the adequacy of a moving-point-source system for measuring shielding characteristics in multiple-structure situations.

\subsection{ECOLOGICAL APPLICATIONS}

A potential future use of fallout simulants may well emerge as the by-product of a study such as the one outlined in this report. Fallout simulants incorporating nuclear-reactionderived isotopes could be used to determine the biological cycling of radioactive materials as they move from the environment to the dinner table..$^{13}$

\section{REFERENCES}

1. Civil Defense for National Survival, Parts 1-7, Hearings, Subcommittee of the Committee on Government Operations, 84th Congress, 2nd Session, 1956.

2. Herman Kahn et al., Report on a Study of Nonmilitary Defense, Rand Corporation, Report R-322-RC, 1959.

3. W. E. Strope, Evaluation of Countermeasure System Components and Operational Procedures, Project 32.3, Operation Plumbbob Report, WT-1464, August 1958.

4. F. P. Cowan, The Accumulation of Radioactive Fallout on Typical Materials of Construction, Report BNL-497, Brookhaven National Laboratory, March 1958.

5. R. T. Graveson, Radiation Protection Within a Standard Housing Structure, Report NYO4714, New York Operations Office, November 1956.

6. A. J. Breslin and L. R. Solon, Fallout Countermeasures for AEC Facilities, Report NYO4682-A, New York Operations Office, December 1955.

7. S. Glasstone, Ed., "The Effects of Nuclear Weapons," Superintendent of Documents, U. S. Government Printing Office, Washington 25, D. C., June 1957. 
8. L. Machta and K. M. Nagler, Meteorology - Fallout and Weathering, in "The Shorter-Term Biological Hazards of a Fallout Field," Superintendent of Documents, U. S. Government Printing Office, Washington 25, D. C., December 1956.

9. N. M. Lulejian, Radioactive Fallout From Atomic Bombs, Report C3-36417(Del.), Air Research and Development Command, Andrews AFB, Md., November 1953.

10. L. E. Egeberg, Fallout Studies and Assessment of Radiological Phenomena, Project 32.4, Operation Plumbbob Report WT-1465, Naval Radiological Defense Laboratory, November 1959.

11. J. A. Auxier et al., Experimental Evaluation of the Radiation Protection Afforded by Residential Structures Against Distributed Sources, Report CEX-58.1, Jan. 19, 1959.

12. T. D. Strickler and J. A. Auxier, Experimental Evaluation of the Radiation Protection Afforded by Typical Oak Ridge Homes Against Distributed Sources, Report CEX-59.13, Apr. 14, 1960.

13. New York Operations Office, Health and Safety Laboratory, Environmental Contamination from Weapons Test, Report HASL-42, October 1958. 


\section{Chapter 2}

\section{THE FALLOUT SIMULANT PROBLEM}

\subsection{RATIONALE}

The lack of information on the distribution of fallout in densely populated areas, the need for the data in developing fallout protective measures in urban and suburban residential and other multiple-structure areas, and the improbability of developing the data from weapons fallout furnish the essential reasons for turning to the consideration of a realistic simulant to supply essential data.

Some means of cross-checking data is desirable, especially in situations in which assumptions and approximations must be used in evaluating relevant variables, including effect of the interaction of weather, structure, and complex building arrays on fallout distribution. It remains to be determined whether or not, and to what extent, some measure of predictability can be established for such situations. Several reasonably probable extreme situations can be imagined. Consider, for example, a block of closely spaced houses all having smooth roof surfaces; consider that a light wind is blowing parallel with the street. Fallout from the roofs and eddies at the cross streets and alley ends of the buildings could create quite a different hazard to occupants of the buildings than a situation in which buildings were in contact, or nearly so, and the roof surfaces were of a material that would retain a maximum of small particles. Such a large number of conditions are possible that it would not be within the scope of this report to try to anticipate them. What is important in any case is a knowledge of the shadowing or mutual shielding aspects in complex building configurations and of the effects of differing structural materials on fallout distribution. The irregularities of both these radiological parameters may prove to be more or less typical and hence predictable within reasonable limits.

\subsection{FALLOUT DISTRIBUTION}

The influence of grouped structures and weather conditions on the distribution of fallout can be studied with a brilliantly colored or fluorescent simulant before further and more complete studies with a radioactive additive are undertaken. This procedure would be the logical first phase of an operational simulant study. Such a procedure would be important to the development of techniques and operational skills as well as important in obtaining data on the vagaries of fallout distribution in complex situations.

In addition, the use of such a "dummy" simulant in connection with the existing CETO Mobile Radiological Measurement Unit system would provide an experimental means of checking the adequacy and correctness of the source routing for unusual situations in which the assumption of a ground-level infinite-plane dose pattern is obviously not realistic.

\subsection{MULTIPLE-STRUCTURE SHIELDING CONSIDERATIONS}

In a consideration of structure shielding the following observations should be noted:

1. Recently constructed suburban housing tends toward a uniform type of construction with 
the individual family units being well separated from each other on all sides by open areas. This situation comes closest to previous test conditions using isolated structures exposed to infinite-plane doses of radiation.

2. Older homes located in many urban areas are characteristically built with little or no separation between individual buildings, thus presenting a virtually unbroken wall to the street front.

3. Downtown business areas vary from collections of unrelated small structures closely situated in the small city to large structures or multistoried skyscrapers in metropolitan areas.

If one were to progress from the case for suburban dwellings through many variations to the case for older urban areas and then to downtown business areas, it can readily be seen the self-shielding of a structure becomes less important and that shielding from adjacent structures becomes more important, although the relative importance is variable, in a determination of over-all protection. 


\section{Chapter 3}

\section{PREPARATION OF A SIMULANT}

\subsection{PROPERTIES AND TEST CONDITIONS}

The simulant should be comparable to weapons-produced fallout in the density and particle size at the chosen distance and in the gamma emission energy of the selected isotope or isotopes. Particle size should be chosen so that, with a selected wind structure, particles would be readily deposited in a controlled fashion on the test area with minimum deposition elsewhere.

Realization of the principal objective of the study as outlined will require the availability of a suitable building complex in a good state of repair. The feasibility of any operational phases of this study is further dependent on the availability or development of the site and facilities for processing the simulant. The development of suitable spreading techniques is considered in Chap. 4. It is assumed for the purpose of this report that the security of a test area during, and subsequent to, any operational runs and any indicated clean-up would present no serious deterrent to the successful completion of the project.

\subsection{SCALING}

In the discussion that follows, all scaling is done according to the scaling rules appearing in The Effects of Nuclear Weapons. ${ }^{1}$ Estimates are based on a 1-Mt surface burst with a constant 15 -mph effective wind velocity. The selected fallout target area $^{2}$ of about $57,000 \mathrm{ft}$, which is comparable to eight 50 - by $144-\mathrm{ft}$ city lots, can be represented by a circle with a radius of $135 \mathrm{ft}$ situated 60 miles downwind from Ground Zero (GZ). Particle sizes are calculated for an average fall from $80,000 \mathrm{ft}$. Table 3.1 shows pertinent data used to arrive at the selected target distance of 60 miles downwind.

At this distance a conventional type dwelling would escape even minimal blast and thermal damage but still might receive sufficient fallout that the residual gamma radiation of $100 \mathrm{r} / \mathrm{hr}$ would represent a significant hazard to the occupants. It is considered that the ratio between fallout density and expected dose rate at the time of arrival for a distance of 60 miles is optimal for convenient scaling down of both quantities for reasons of ease of handling, economy in use of radioactive materials, and minimizing hazard to personnel.

No attempt is made to duplicate exactly the time pattern of fallout arrival. Normally fallout is expected to arrive over a period of hours. When a small area is being contaminated with a given amount of airborne simulant, due regard being paid to wind effects, the fallout is treated as having arrived essentially as a single event. For making comparative measurements, such as relative protection factors, attenuations, and related variables, this approach is adequate and offers definite operational advantages. 
TABLE 3.1-FALLOUT DEPOSITION CHARACTERISTICS FOR A 1 -MT SURFACE BURST

\begin{tabular}{cccccc}
\hline $\begin{array}{c}\text { Dose rate } \\
\text { at } 1 \mathrm{hr}, \\
\mathrm{r} / \mathrm{hr}\end{array}$ & $\begin{array}{c}\text { Downwind } \\
\text { distance, } \\
\text { miles }\end{array}$ & $\begin{array}{c}\text { Estimated } \\
\text { fallout density, } \\
\text { tons/sq mile }\end{array}$ & $\begin{array}{c}\text { Average } \\
\text { particle size, } \\
\mu\end{array}$ & $\begin{array}{c}\text { Time of } \\
\text { arrival, } \\
\mathrm{hr}\end{array}$ & $\begin{array}{c}\text { Dose rate } \\
\text { at time of } \\
\text { arrival, r/hr }\end{array}$ \\
\hline 3,000 & 22 & 12,750 & 250 & 1.47 & 1,800 \\
1,000 & 40 & 4,250 & 200 & 2.66 & 350 \\
500 & 60 & 2,125 & 150 & 4.0 & 100 \\
300 & 70 & 1,275 & 135 & 4.65 & 45 \\
100 & 114 & 425 & 100 & 7.6 & 9 \\
\hline
\end{tabular}

\subsection{MATERIALS AND GENERAL METHOD OF PREPARATION}

The base material for the simulant should be similar in physical characteristics to fused soil particles. Sand is a reasonable approximation of fused soil and offers the practical advantages of availability and ease of handling. Sand and sandlike minerals have previously been used as fallout simulants.

The average particle size is considered to be $150 \mu$. This size is indicated by an analysis of normal soil. However, since the actual particle size deposited at any given point varies over a considerable range, as well as being dependent on the type of soil, reasonable tolerances above and below $150 \mu$ should be allowed.

It is believed that a single radioactive constituent such as $\mathrm{Ba}^{140}-\mathrm{La}^{140}$ is entirely adequate for the type of radiological measurements contemplated. $\mathrm{Ba}^{140}-\mathrm{La}^{140}$ offers the advantages of ready availability, ease of handling and detection, and convenient half life. Furthermore, it has a reasonable approximation of the average gamma energy spectrum of close-in fallout. In this respect, although theoretical compilations of early fission-product spectra show a high contribution by short-lived isotopes with average energy well above the assumed $0.7-\mathrm{Mev}$ average for fallout, ${ }^{2}$ such high-energy components are not present in actual gamma spectral analyses of close-in fallout. ${ }^{3}$

The quantities of base material and radioactivity per simulant drop can be accurately scaled down for reason of economy, ease of handling, and safety to personnel. It is essential only that the quantity of base material be sufficient to permit ready visual detection of nonuniformity in deposition pattern on various test surfaces of target structures and that the amount of radioactivity be sufficient to provide convenient levels for reliable dosimetry. It is estimated that to meet these requirements would require a minimum of 75 to $100 \mathrm{lb}$ of base material and 200 to 400 curies of $\mathrm{Ba}^{140}-\mathrm{La}^{140}$ for each drop.

The minimum quantity of 75 to $100 \mathrm{lb}$ of base material per drop was arrived at using the following estimates: The total mass of fallout calculated for the target area was $3150 \mathrm{lb}$. This quantity is equivalent to approximately $25 \mathrm{~g} / \mathrm{sq}$ ft. This amount of $150-\mu$-diameter sand spread evenly would deposit approximately one layer thick. It has been determined experimentally that $0.5 \mathrm{~g} / \mathrm{sq}$ ft is the minimum that can be detected visually even with a bright dyestuff incorporated. This represents a reduction of 50 , which gives $63 \mathrm{lb}$ as the minimum mass.

The following method of bonding the $\mathrm{Ba}^{140}-\mathrm{La}^{140}$ activity to the simulant base material ${ }^{4}$ appears to be entirely satisfactory: Screened sand is placed in a heated, rotating cement mixer; the active $\mathrm{Ba}^{140}-\mathrm{La}^{140}$ solution is sprayed on and dried; a bonding solution of sodium silicate (water glass) is sprayed on and dried; and the sand is thoroughly mixed. The resulting product is ready for use without further treatment. The principal objection to the use of Monterey type sand for the simulant is that its glasslike nature restricts the radioactive additive almost entirely to the surface of the granules. Where a relatively weak tracer activity is bonded to a very large quantity of sand, this characteristic would not present a serious problem; but, since in the use outlined in this report a much greater quantity of radioactivity (200 to 400 curies) will be incorporated into a relatively small $(75$ to $100 \mathrm{lb}$ ) amount of sand, uniform distribution and firm adherence of the active material is of utmost importance. 
Owing to the much larger quantities of radioactive material that would be carried on the individual sand grains, the use of sand of volcanic origin is indicated because of its vesicular nature. Sand of this type is commonly sold as "light aggregate."

In the drying process, it is expected that both the activity and the sodium silicate would be withdrawn into the pores of a volcanic sand, thus ensuring better uniformity and retention. After the sand has been treated with sodium silicate, the final product should have a density approaching that of normal soil.

It is very desirable to incorporate a highly visible substance such as a brightly colored dyestuff or pigment or a fluorescent material into the bonding mixture. The material would serve a twofold purpose: It would serve as a convenient visual or instrumentally measured indicator in preliminary tests with nonactive simulant to determine the distribution of the fallout simulant in a building complex; and, incorporated into the active simulant, it would permit ready visual detection of significant differences in local deposition patterns, which can then be correlated with actual dose rates obtained by instrumental measurements. Such a visual indicator material can be very conveniently incorporated in the sodium silicate bonding solution.

\subsection{PREPARATION OF ACTIVE SOLUTION}

The activity probably would be in the form of an acid-soluble salt such as $\mathrm{Ba}\left(\mathrm{NO}_{3}\right)_{2}$ or $\mathrm{BaCl}_{2}$. Since the activity would be applied from a water solution, adequate hot-cell facilities are necessary for this operation. A liquid reservoir for the sprayer would be in the hot cell, connected by Tygon tubing to the mixer, which would be isolated by a thick wall of shielding. Mixer and hot cell would have to be fairly close together to facilitate handling and transit.

\subsection{QUANTITY OF $\mathrm{Ba}^{140}-\mathrm{La}^{140}$ INVOLVED}

It is suggested that ground-level dose rates be 1 to $2 \mathrm{r} / \mathrm{hr}$, a level that would permit measurements in the area within a 2 - to 4 -hr period after the simulant reaches the surface.

If a shielding factor of 100 is assumed, a $1 \mathrm{r} / \mathrm{hr}$ radiation field would be adequate for reliable data collection with suitable dosimeters within 3 to $4 \mathrm{hr}$ from exposure time, or less, depending on the sensitivity of the detectors. If the attenuation factor is in the range 100 to 2000 , a radiation field of 1 to $2 \mathrm{r} / \mathrm{hr}$ would still be satisfactory if low-range ion chambers (0 to 10 $\mathrm{mr}$ ) were exposed for 3 to $4 \mathrm{hr}$. However, attenuation factors of 10,000 or more would require proportionately larger dose rates above ground or more sensitive detector systems.

To create a radiation field of 1 or $2 \mathrm{r} / \mathrm{hr}$ over the entire target area would require 200 to 400 curies of $\mathrm{Ba}^{140}-\mathrm{La}^{140}$ per drop. If more than one drop or higher dose rates should be planned for a given experiment, correspondingly larger quantities of $\mathrm{Ba}^{140}-\mathrm{La}^{140}$ would have to be processed and handled.

\subsection{TRANSPORT OF ACTIVE SIMULANT}

The prepared active simulant should be discharged directly into a truck or trailer provided with slab shielding behind the driver's compartment and a well type cave shield surrounding the charge container. It is estimated that not more than 15 tons of concrete (or lead bricks) would be adequate shielding on the truck. After the simulant has been transported to the target site, hookup leads should be connected and the charge should be elevated. The truck and crew should then leave the area for check-out and decontamination as needed.

\section{REFERENCES}

1. S. Glasstone, Ed., "The Effects of Nuclear Weapons," Superintendent of Documents, U. S. Government Printing Office, Washington 25, D. C., June 1957. 
2. R. C. Bolles and N. E. Ballou, Calculated Activities and Abundances of $U^{235}$ Fission Products, Report USNRDL-456, Naval Radiological Defense Laboratory, Aug. 30, 1956.

3. P. LaRiviere, personal communication.

4. J. Sartor, Radiological Reclamation of Land Areas, Part 3, Program B-3, Problem 3, Naval Radiological Defense Laboratory (in preparation). 


\section{Chapter 4}

\section{DISPERSAL OF THE SIMULANT}

\subsection{GENERAL CONSIDERATIONS}

Several possible methods have been considered for obtaining desired airborne dispersal over the prescribed target area. The method chosen must meet the following conditions:

1. It must assure adequate uniformity of dispersion.

2. It must be reliable and simple, requiring a minimum of intricate machinery.

3. It must be mobile so that it can be moved to various target areas as needed.

4. There must be a minimum exposure hazard. The dispersal equipment must be completely unmanned or remotely operated.

5. The entire deposit should be laid down in a fairly short time to facilitate early measurements and to minimize hazards and effects of weather changes.

The methods that have been considered are as follows:

1. Elevated air-or water-pressure spray nozzles.

2. Modified crop-dusting techniques with a helicopter,

3. Air showering of a zone-melted fuel element.

4. An explosive charge or a rapid high-pressure gas-release system suspended beneath a balloon or a helicopter (or, possibly, mounted on a high tower).

\subsection{ELEVATED AIR- OR WATER-PRESSURE SPRAY-NOZZLE SYSTEM}

This method has been used in experiments ${ }^{1}$ to disperse simulants for decontamination studies. However, for the application considered in this report, it is not feasible for use because buildings would vary in height and spatial configurations.

\subsection{MODIFIED CROP-DUSTING TECHNIQUE USING A HELICOPTER}

A modified crop-dusting technique with a helicopter has been considered in previous simulant work. Because of the localized nature of the target area and the aim of centering the fallout over about $57,000 \mathrm{sq} f \mathrm{ft}$ of a building complex, a large helicopter would be the only vehicle that could be used in this method. The dusting equipment would need to be suspended from the aircraft by a long cable to reduce personnel exposure. If the separation is adequate for safety, the down draft of the rotors probably would not affect the dispersion. Trial runs would have to be made to establish this point. The helicopter could circle the area while laying down the simulant. This method is not considered to be as economical as the accurately positioned and explosively dispersed simulant that is described later. However, it does offer some advantage of speed and mobility. 
Air showering of a zone-melted fuel element is at present being used for Air Force studies involving downwind contamination. ${ }^{2}$ Personnel hazards, the long-lived activity of the fallout debris, and the multiple health monitoring processes necessary make this method unsuitable for attaining the objectives of this experiment.

\subsection{EXPLOSIVE-CHARGE AND RAPID HIGH-PRESSURE GAS-RELEASE SYSTEM SUS- PENDED BENEATH A BALLOON OR HELICOPTER}

Of the various methods considered, the explosive-charge and the rapid high-pressure gasrelease systems are the two that are recommended for investigation.

Most of the procedures and operational facilities planned or necessary up to actual transfer of the material from the transportation truck to the distribution system would be exactly the same for both these methods. In general, either the balloon or helicopter discharge system, by explosive charge or rapid high-pressure gas-release devices, can be described in the same manner. However, certain details that are different, would allow a choice of one method over the other based on economic and feasibility factors.

In a review of the two methods, several pertinent points should be considered:

1. Simulant preparation and transportation problems are the same.

2. The basket or container and hookup problems would vary according to the type of dispersal charge and vehicle used. Two dispersal systems have been considered: One is a Primacord directional type explosive unit remotely triggered by a coded tone receiver; the second is a rapid gas-release system triggered in somewhat the same manner. The triggered system would allow a detonation delay so that simulant ejection would take place at the end of a drop cord of specified length. This arrangement would allow reuse of the overhead shield, the tone receiver, and the balloon (if used) with its associated hardware.

3. Balloon positioning could be accomplished by either two or three fixed cable tie points with a central cable for raising and lowering the unit, thus permitting mobility, flexibility, and accurate positioning. The balloon suspension system offers the advantage of remote operation. It is believed that the captive-balloon suspension method would be as satisfactory as any; and it has definite advantages in terms of simplicity, safety, and low cost.

4. Factors to be considered in the use of the helicopter suspension system include crew members, height of burst, and the length of separation cable between simulant package and helicopter. The helicopter would contain radio equipment, radioactive monitoring gear, a detonation device, and sighting gear. Small preshot changes in wind direction or velocity could be compensated for by ground correction.

5. Regardless of whether the balloon or the helicopter suspension system is used, the dispersal charge must be at a sufficient height to avoid any local blast effects on the target below. It is estimated that a distance of at least $200 \mathrm{ft}$ between the charge and the target would be needed. With the use of light aircraft cable, a single 35 -ft balloon should be adequate for loads up to $200 \mathrm{lb}$.

\section{REFERENCES}

1. J. Sartor, Radiological Reclamation of Land Areas, Part 4, Program B-3, Problem 3, Naval Radiological Defense Laboratory (in preparation).

2. Convair, Fission Products Field Release Test-I, Report NARF-59-32T, September 1959. 


\section{Chapter 5}

\section{DOSIMETRY}

\subsection{DOSE RATES AND ATTENUATION FACTORS}

Approximate dose rates at points of interest, derived by utilizing attenuation factors for a typical residential shelter or house, for various amounts of deposited simulant are given in Table 5.1, which shows the relation between the amount of $\mathrm{Ba}^{140}-\mathrm{La}^{140}$ activity required and the resulting dose rates that would be obtained under various degrees of attenuation. This relation is an approximation for orders of magnitude only and does not take into consideration radiation contributions from areas beyond the test area of $57,000 \mathrm{sq} \mathrm{ft}$.

In a built-up area, mutual shielding by buildings close together would further reduce the effective radius of a uniform field of fallout as opposed to the case of an isolated structure, with the assumption that the simulant would be uniformly distributed over the test area for each case.

The following calculations were used in arriving at the values shown: 1 sq mile $=27,878,400$ $\mathrm{sq} \mathrm{ft} ; 135-\mathrm{ft}$ radius circle $=57,257 \mathrm{sq} \mathrm{ft} ;$ and $10^{6} \mathrm{curies} / \mathrm{sq}$ miles $=2460 \mathrm{curies} / 135-\mathrm{ft}$ radius circle.

The average photon energy of a $\mathrm{Ba}^{140}-\mathrm{La}^{140}$ equilibrium mixture would be about $1.1 \mathrm{Mev}$. The dose rate $3 \mathrm{ft}$ above the ground would be approximately $6 \mathrm{r} / \mathrm{hr}$ for a uniform contamination of $10^{6}$ curies/sq mile.

\subsection{DOSIMETRY}

In general, dosimetry should be consistent with requirements of related CETO projects. ${ }^{1,2}$ High-level dosimetry (greater than 100-mr total dose) should present no new problems. Techniques that have proved satisfactory for space and area dosimetry of standing structures in previous CETO exercises would be applicable. Established principles and methods, including the use of teams to minimize individual exposure, adequate radiation protective clothing, means of rapid ingress and egress, should be observed. Owing to the much lower dosage levels (less than 100-mr total dose) expected in high attenuation areas, such as in basements and shelters, special precautions should be taken to prevent the introduction of contamination into them dur-

ing recovery operations. For this reason remote read-out methods may be advisable in these areas to ensure maximum utilization of the data generated by the simulated fallout field.

\section{REFERENCES}

1. T. D. Strickler and J. A. Auxier, Experimental Evaluation of the Radiation Protection Afforded by Typical Oak Ridge Homes Against Distributed Sources, Report CEX-59.13, Apr. 14, 1960.

2. J. A. Auxier et al., Experimental Evaluation of the Radiation Protection Afforded by Resi dential Structures Against Distributed Sources, Report CEX-58.1, Jan. 19, 1959. 
TABLE 5.1-DOSE RATES WITH TYPICAL ATTENUATION FACTORS

\begin{tabular}{|c|c|c|c|c|c|c|}
\hline \multirow[b]{2}{*}{$\begin{array}{c}\mathrm{Ba}^{140}-\mathrm{La}^{140}, \\
\text { curies }\end{array}$} & \multirow{2}{*}{$\begin{array}{l}\text { Approximate } \\
\text { ground-level } \\
\text { dose rate, r/hr }\end{array}$} & \multicolumn{5}{|c|}{ Dosages, $\mathrm{r} / \mathrm{hr}$} \\
\hline & & $\begin{array}{l}\text { Second floor } \\
\text { (Att. }=2 \text { ) }\end{array}$ & $\begin{array}{l}\text { First floor } \\
\text { (Att. }=10)\end{array}$ & $\begin{array}{c}\text { Basement } \\
\text { (Att. = 100) }\end{array}$ & $\begin{array}{c}\text { Shelter } \\
(\text { Att. }=1000)\end{array}$ & $\begin{array}{c}\text { Shelter } \\
(\text { Att. }=10,000)\end{array}$ \\
\hline 2400 & 6.0 & 3.0 & 0.6 & 0.06 & 0.006 & 0.0006 \\
\hline 400 & 1.0 & 0.5 & 0.1 & 0.01 & 0.001 & 0.0001 \\
\hline 200 & 0.5 & 0.25 & 0.05 & 0.005 & 0.0005 & \\
\hline 100 & 0.25 & 0.13 & 0.025 & 0.0025 & & \\
\hline 40 & 0.1 & 0.05 & 0.001 & 0.0001 & & \\
\hline
\end{tabular}




\section{Chapter 6}

\section{CONCLUSIONS AND RECOMMENDATIONS}

\subsection{CONCLUSIONS}

The data envisaged in this study are important to mass survival in the event of nuclear attack or serious nuclear accident in order that:

1. Adequate information on the radiation protection and mutual shadowing afforded by existing grouped buildings and structures of various types may be obtained.

2. Modification to such grouped structures may be specified to obtain predictable protection factors for fallout.

3. New construction may be undertaken with reliable knowledge of the radiation protection factors afforded by them in specified locations and configurations.

4. Data obtained by means of the CETO Mobile Radiological Measurement Unit may be more adequately correlated with actual fallout measurements.

5. Experimental verification and increased confidence may be generated for the use of the CETO Mobile Radiological Measurement Unit and related techniques.

\subsection{RECOMMENDATIONS}

The reasonableness and feasibility of an observational and experimental study to acquire such data are indicated and should be undertaken. 


\section{CIVIL EFFECTS TEST OPERATIONS REPORT SERIES (CEX)}

Through its Division of Biology and Medicine and Civil Effects Test Operations Office, the Atomic Energy Commission conducts certain technical tests, exercises. surveys, and research directed primarily toward practical applications of nuclear effects information and toward encouraging better technical, professional, and public understanding and utilization of the vast body of facts useful in the design of countermeasures against weapons effects. The activities carried out in these studies do not require nuclear detonations.

A complete listing of all the studies now underway is impossible in the space available here. However, the following is a list of all reports available from studies that have been completed. All reports listed are available from the Office of Technical Services, Department of Commerce, Washington 25. D. C., at the prices indicated.

CEX-57.1 The Radiological Assessment and Recovery of Contaminated (\$0.75) Areas, Carl F. Miller, September 1960.

CEX-58.1 Experimental Evaluation of the Radiation Protection Afforded by (\$2.75) Residential Structures Against Distributed Sources, J. A. Auxier, J. O. Buchanan, C. Eisenhauer, and H. E. Menker, January 1959.

CEX-58.2 The Scattering of Thermal Radiation into Open Underground (\$0.75) Shelters, T. P. Davis, N. D. Miller, T. S. Ely, J. A. Basso, and H. E. Pearse, October 1959.

CEX-58.7 AEC Group Shelter. AEC Facilities Division, Holmes \& Narver, (\$0.50) Inc., June 1960.

CEX-58.8 Comparative Nuclear Effects of Biomedical Interest, Clayton S.

(\$1.00) White, I. Gerald Bowen, Donald R. Richmond, and Robert L. Corsbie, January 1961.

CEX-58.9 A Model Designed to Predict the Motion of Objects Translated by

(\$1.25) Classical Blast Waves, I. Gerald Bowen, Ray W. Albright, E. Royce Fletcher, and Clayton S. White, June 1961.

CEX-59.1 An Experimental Evaluation of the Radiation Protection Afforded

$(\$ 0.60)$ by a Large Modern Concrete Office Building, J. F. Batter, Jr., A. L. Kaplan, and E. T. Clarke, January 1960.

CEX-59.4 Aerial Radiological Monitoring System. 1. Theoretical Analysis,

(\$1.25) Design, and Operation of a Revised System, R, F. Merian, J. G. Lackey, and J. E. Hand, February 1961.

CEX-59.13 Experimental Evaluation of the Radiation Protection Afforded by

(\$0.50) Typical Oak Ridge Homes Against Distributed Sources, T. D. Strickler and J. A. Auxier, April 1960.

CEX-59.14 Determinations of Aerodynamic-drag Parameters of Small Irregular

(\$1.75) Objects by Means of Drop Tests, E. P. Fletcher, R. W. Albright, V. C. Goldizen, and I. G. Bowen, October 1961.

CEX-60.1 Evaluation of the Fallout Protection Afforded by Brookhaven

(\$1.75) National Laboratory Medical Research Center, H. Borella, Z. Burson, and J. Jacovitch, February 1961.

CEX-60.5 Experimental Evaluation of the Fallout-Radiation Protection

(\$0.50) Afforded by a Southwestern Residence, Z. Burson, D. Parry, and H. Borella, February 1962.

CEX-62.01 Technical Concept-Operation Bren, J. A. Auxier, F. W.

$(\$ 0.50)$ Sanders, F. F. Haywood, J. H. Thorngate, and J. S. Cheka, January 1962. 